\title{
Mass Treatment does not reduce the prevalency of parasites in Guarani indigenous
}

\section{schoolchildren in Brazil}

\author{
Tratamento em massa não reduz a prevalência de parasitos em escolares indígenas Guarani no
}

Brasil

Tratamiento masivo no reduce la prevalencia de parásitos en escolares indígenas Guaraní en Brasil

\begin{abstract}
The high frequency of intestinal parasites is favored by environmental and socio-cultural conditions of indigenous populations, and is still a neglected public health problem. Mass administration of broad-spectrum drugs aims to reduce the prevalence and intensity of the infections. The prevalence of intestinal parasites in school-children in an indigenous Guarani village in southern Brazil, was evaluated before and after the mass treatment of the population with albendazole. In the first phase of collection of stool samples, $81.4 \%$ of them were positive for enteroparasites and in the second phase, after two doses of antiparasitic medication, $87.5 \%$ were positive. Although the prevalence of infections by some helminths has reduced after treatment, many parasites remained frequent in the studied population, showing a change in the epidemiological profile in the distribution of these diseases in the population. The prevalence of intestinal parasites in indigenous schoolchildren proved to be high even after mass treatment with albendazole.
\end{abstract}

Keywords: Indigenous population; Parasitic diseases; Agents antiparasitic.

\section{Resumo}

A alta frequência de parasitoses intestinais é favorecida por condições ambientais e socioculturais das populações indígenas, sendo ainda um problema de saúde pública negligenciado. A administração em massa de medicamentos de amplo espectro busca reduzir o número e a intensidade das infecções. Avaliou-se a prevalência de parasitoses intestinais em escolares de uma aldeia indígena Guarani no sul do Brasil, antes e após o tratamento em massa da população com o albendazol. Na primeira fase de coleta das amostras de fezes, $81,4 \%$ delas apresentaram-se positivas para enteroparasitos e na segunda fase, após duas doses de antiparasitário, 87,5\% apresentaram-se positivas. Embora a prevalência de infecções por alguns helmintos tenha reduzido após o tratamento, muitos parasitos continuaram frequentes na população estudada, mostrando uma mudança no perfil epidemiológico de distribuição dessas doenças 
na população. A prevalência de enteroparasitoses nos escolares indígenas mostrou-se elevada mesmo após o tratamento em massa com albendazol.

Palavras-chave: População indígena; Doenças parasitárias; Agentes antiparasitários.

\section{Resumen}

La alta frecuencia de parásitos intestinales se ve favorecida por las condiciones ambientales y socioculturales de las poblaciones indígenas, y sigue siendo un problema de salud pública desatendido. La administración masiva de fármacos de amplio espectro tiene como objetivo reducir la prevalencia y la intensidad de las infecciones. Se evaluó la prevalencia de parásitos intestinales en escolares de una aldea indígena Guaraní en el sur de Brasil, antes y después del tratamiento masivo de la población con albendazol. En la primera fase de la recogida de muestras de heces, el $81,4 \%$ de ellas fueron positivas para enteroparásitos y en la segunda fase, tras dos dosis de medicación antiparasitaria, el $87,5 \%$ fueron positivas. Aunque la prevalencia de infecciones por algunos helmintos se ha reducido después del tratamiento, muchos parásitos se mantuvieron frecuentes en la población estudiada, mostrando un cambio en el perfil epidemiológico en la distribución de estas enfermedades en la población. La prevalencia de parásitos intestinales en escolares indígenas resultó ser alta incluso después del tratamiento masivo con albendazol.

Palabras clave: Población indígena; Enfermedades parasitarias; Agentes antiparasitarios.

\section{Introduction}

Intestinal parasitic infections are among the main diseases in developing countries and are considered by the World Health Organization (WHO) as neglected tropical diseases (Hotez, 2009).

In indigenous villages, even with the implementation of sanitation actions, health services are often unable to control these infections. This is due to the high rates of transmission of parasitosis, which are favored by the environmental and sociocultural conditions of these populations, which is still a relevant public health problem (Faustino et al., 2008; Echagüe et al., 2015; Scolari at al., 2000; Toledo et al., 2009).

The indigenous populations present in the State of Paraná, in the southern region of Brazil, belong to the Kaingang and Guarani ethnic groups, with some remaining Xetá (Novak \& Mota, 2016).

Different authors have investigated the presence of enteroparasites mainly in the indigenous Kaingang people (Toledo et al., 2009; Novak \& Mota, 2016; Silva et al., 2016a), but also in the peridomiciliar soil and drinking and recreation water of the indigenous villages where they live (Moura et al, 2010; Silva et al., 2016b), as well as the identification of local risk areas for acquisition of these infections (Silva et al., 2016b).

High prevalence of enteroparasites have been recorded in indigenous populations in Paraná, ranging from $67 \%$ to 95\%, according to the region studied (Toledo et al., 2009; Silva et al., 2016a). In Kaingang lands, the frequency of peridomiciliar soil samples contaminated by enteroparasites of humans or animals with zoonotic potential ranged from $75.7 \%$ to $96.2 \%$ (Moura et al., 2010) and water contamination with waterborne protozoa, such as Giardia spp and Cryptosporidium spp, was also observed (Nishi et al., 2009). These findings indicate that the treatment of human and animal excrement in indigenous lands is inadequate and improvements in sanitation and water treatment, in addition to periodic treatment of the population with antiparasitic agents, are necessary (Scolari et al., 2000; Toledo et al., 2009; Silva et al., 2016a; Moura et al, 2010; Silva et al., 2016b; Nishi et al., 2009).

The treatment of geo-helminthiasis in children in the school environment is an effective way for controlling these parasites, since geo-helminths do not multiply in the human host and the administration of broad-spectrum drugs reduces both the prevalence of the disease, as the intensity of infection in the individual or in the locality where they live (Coimbra et al., 2005). When selecting areas for intervention, priority should be given to locations with a high prevalence of geo-helminth infections, as well as those with poor basic sanitation conditions, such as water supply and sewage collection and treatment (Ministério da Sáude Brasil, 2018).

Studies with Guarani indigenous populations in southern Brazil show that treatment with antiparasitic drugs has been one of the measures adopted for infection control, with albendazole being used on a large scale as treatment for this population 
(Diehl e Grassi, 2010; Brandelli et al., 2012).

According to WHO (2018), periodic treatment is a preventive and effective measure to reduce the parasitic burden and its consequences. For the control strategy in schools give good results, it is necessary to plan activities following the steps that go from a good articulation between the local health and education system, to the monitoring and evaluation of the intervention.

In this study, due to the lack of data regarding parasitological health indicators in the Guarani indigenous people and the effectiveness of parasitic treatment in this group, we aimed to evaluate the frequency of intestinal parasitosis in school-aged children in a Guarani indigenous village in the State of Paraná, before and after treatment with antiparasitic medication adopted as the only action to control these diseases.

\section{Methodology}

\subsection{Ethical aspects}

The research was approved by the National Research Ethics Commitee - CONEP, with registration number 1.756.060/2016, with participation in the study conditioned on the parents or guardians signing the Free and Informed Consent Form - FICF. There was also approval by local indigenous leaders and by the Litoral Sul Special Indigenous Sanitary District (DSEI), in which the indigenous village studied is located.

\subsection{Study area and population}

The study was conducted at the indigenous school of Ocoy Indigenous Land (IL), western region of the State of Paraná (252 $\left.20^{\prime} 50^{\prime \prime} \mathrm{S}, 54^{\circ} 14^{\prime} 6^{\prime \prime} \mathrm{O}\right)$, southern Brazil.

This village has an area of 251 hectares inhabited by about 900 people belonging to the Guarani ethnic group and distributed in 106 households with a population concentration at the younger age groups (IBGE, 2020).

The village is $18.2 \mathrm{~km}$ from the municipality of São Miguel do Iguaçu, and the access is partially paved. Some indigenous people work outside the village in agricultural and avian cooperatives. There is electricity and water supply network and there is no paving within the village. Structurally, the village has a Crafts and Nutrition Center, a Prayer House, a school and a Basic Health Unit (UBS). The local UBS has daily assistance from a nurse, indigenous and non-indigenous health agents and, weekly, it is attended by a doctor and dentist.

\subsection{Population sample}

After meeting with the local UBS team, it was established that indigenous health agents (IHA) would make direct contact with the villagers, aiming to increase the adherence of the population to the study. The studied sampling structure consisted of 396 students aged between 5 and 19 years old, matriculated at the local indigenous school. The sample size was calculated using the software StatiDisk Version 8.4, considering the samplying structure, a 95\% confidence level, an error of $10 \%$ and a prevalence of $90 \%$ for intestinal parasitosis in indigenous villages in Paraná (Toledo et al., 2009), the required sample of at least 32 people in each assessment. This is a quantitative descriptive research (Pereira etal, 2018) where the population sample consisted of ramdom students whose parents or guardians voluntarily consented to participate in the research, after an active search by the local health team. Even though some indigenous children were included in the two moments of development of the collections, all were selected randomly.

\subsection{Collection and processing of stool samples}

The collection of stool samples was carried out by parents, guardians or by the children and adolescents themselves 
when they were old enough to understand and proceed with the collection alone, after meeting the research team with members of the indigenous community and their leaders. At this meeting, the objectives and benefits of the research were explained, as well as the correct way to collect the sample. Collection flasks duly identified with the participants' names were delivered along with verbal and written collection instructions, with the help of the community IHAs. Subsequently, the IHAs returned to the participants' homes on the following days to collect the flasks containing the stool samples, which were packaged in cold coolers without the use of chemical preservatives, sent to the Clinical Parasitology laboratory at the State University of Western Paraná, in Cascavel, and maintained at temperature $5{ }^{\circ} \mathrm{C}$, until processing, within 3 days. the transport and conservation of the samples were carried out carefully so as not to alter the morphology of the parasites and the possibility of them meeting.

\subsection{Coproparasitological examinations}

An initial coproparasitological examination (1st examination) was carried out in November 2018 and a monitoring examination (2nd examination), in May 2019, in order to evaluate the effect of the control measure applied. The samples, one per person, were processed and analyzed using three methods of parasitological stool examinations: 1) direct method, in which the sample was processed with saline solution to avoid the loss of species of Blastocystis hominis that might be present in them (Elghareeb et al., 2015); 2) flotation after centrifugation in zinc sulfate solution (Faust et al., 1939); and 3) spontaneous sedimentation in water (Lutz, 1919). The slides were read by an experienced microscopist in 10X and 40X magnification.

The parasitological health indicators evaluated in this study were: total frequency of enteroparasites, frequency by species and polyparasitism, frequency by gender and age group (Montresor et al, 1998). The intensity of infection was not determined since the Kato - Katz quantitative method was not used in this study.

\subsection{Antiparasitic treatment protocol}

After the first collection of fecal material (Initial Examination), a single control measure, which consisted of two antiparasitic treatments, was applied in school-age children. Albendazole (ABZ), a carbamatobenzimidazole agent with anthelmintic and anti-protozoan activity, was used to treat intestinal and tissue parasites. For each student, a single dose of 400 mg of ABZ was administered by the local UBS health team, in two doses with an interval of 90 days between them, according to the protocol adopted by the Litoral Sul DSEI, to control general parasitic infections. Treatment coverage in the population was high and all children involved in the study received the medication. Thirty days after the second dose of ABZ, the 2nd Examination was carried out by collecting new stool samples from the students.

\subsection{Statistical analysis}

The Z Test with the software StatiDisk Version 8.4 was used, comparing the data of the laboratory analysis of the fecal samples, considering the results before and after the antiparasitic treatment of the population studied. Significance levels of $5 \%$ were considered.

\section{Results}

The frequencies of total enteroparasites and species of enteroparasites, and the frequency of polyparasitism, found before and after the mass treatment of the population with antiparasitic medication are showes in Tabel 1 . In the initial examination, before antiparasitic treatment, 43 samples of fecal material were examined; 81.4\% (35/43) were positive for enteroparasites and $48.8 \%$ (21/43) indicated the presence of polyparasitism, and the most common association was 
Hymenolepis nana and Entamoeba coli. Protozoan cysts and helminth eggs were observed in 79.1\% (34/43) and 30.2\% (13/43) of the samples, respectively.

Table 1. Frequency of enteroparasites in school-children in a Guarani indigenous village, State of Paraná, Southern Brazil, before (in November, 2018) and after (May, 2019) treatment with albendazole (400 mg, 2X).

\begin{tabular}{|c|c|c|c|c|c|}
\hline & \multicolumn{2}{|c|}{$\begin{array}{c}\text { 1st Collection - Before } \\
\text { treatment }\end{array}$} & \multicolumn{2}{|c|}{$\begin{array}{c}\text { 2nd Collection - After } \\
\text { treatment }\end{array}$} & \multirow{3}{*}{$p$ value } \\
\hline & \multicolumn{2}{|c|}{$n=43$} & \multicolumn{2}{|c|}{$\mathbf{n}=\mathbf{3 2}$} & \\
\hline & $\mathbf{n}$ & $\%$ & $\mathbf{n}$ & $\%$ & \\
\hline Enteroparasites & 35 & 81.4 & 28 & 87.5 & 0.4760 \\
\hline Polyparasitism & 21 & 48.8 & 17 & 53.1 & 0.7126 \\
\hline Protozoa & 34 & 79.1 & 27 & 84.4 & 0.5599 \\
\hline Entamoeba coli & 18 & 41.9 & 15 & 46.9 & 0.6662 \\
\hline Giardia duodenalis & 18 & 41.9 & 8 & 25.0 & 0.1283 \\
\hline Endolimax nana & 16 & 37.2 & 14 & 43.8 & 0.5639 \\
\hline $\begin{array}{c}\text { Entamoeba } \\
\text { histolytica/E. dispar }\end{array}$ & 8 & 18.6 & 13 & 40.6 & $0.0039 *$ \\
\hline Blastocystis hominis & 7 & 16.3 & 1 & 3.1 & $0.0670^{* *}$ \\
\hline Iodamoeba butschillii & 3 & 7.0 & 3 & 9.4 & 0.7051 \\
\hline Helminths & 13 & 30.2 & 14 & 43.8 & 0.2299 \\
\hline Hymenolepis nana & 10 & 23.3 & 14 & 43.8 & $0.0699 * *$ \\
\hline Ancilostomídeos & 4 & 9.3 & 0 & 0.0 & 0.0762 \\
\hline Ascaris lumbricoides & 3 & 7.0 & 0 & 0.0 & 0.1266 \\
\hline Trichuris trichiura & 1 & 2.3 & 0 & 0.0 & 0.3878 \\
\hline
\end{tabular}

Significant (*) and marginally significant $(* *)$ p-value by the Z Test considering a $5 \%$ significance level. Source: Authors.

In the second examination, carried out 30 days after the second dose of the antiparasitic agent, 32 samples of fecal material were collected; $87.5 \%$ (28/32) of them were positive for enteroparasites and 53.13\% (17/28) indicated polyparasitism. The frequencies of protozoa and helminths found in the samples were $84.4 \%$ (27/32) and 37.5\% (12/32), respectively (Table 1). There was no significant difference between the frequencies of enteroparasites (total, specific and polyparasitism) between the two coproparasitological examinations. The only exception was for the frequency of Entamoeba histolytica/E. dispar cysts, which was higher after treatment $(\mathrm{p}=0.0039)$. Although there was no significant difference in the frequency between the two examinations, geo-helminth eggs such as hookworms, Ascaris lumbricoides and Trichuris trichiura, were only detected before the treatment of the population.

The evaluation of the frequency of enteroparasites in indigenous students, according to the age group, showed a significant increase in helminths in children aged between five and nine years after treatment with ABZ (Table 2). 
Table 2. Frequency of protozoa and helminths according to the age group in school-children in a Guarani indigenous village, State of Paraná, southern Brazil, before (in November, 2018) and after (May, 2019) treatment with albendazole (400 mg, 2X).

\begin{tabular}{|c|c|c|c|c|c|}
\hline \multirow{2}{*}{$\begin{array}{l}\text { Age group } \\
\text { (in years) }\end{array}$} & \multicolumn{2}{|c|}{$\begin{array}{l}\text { 1st Collection - Before treatment } \\
\qquad(n=43)\end{array}$} & \multicolumn{2}{|c|}{$\begin{array}{l}\text { 2nd Collection - after treatment } \\
\qquad(\mathrm{n}=32)\end{array}$} & \multirow[b]{2}{*}{$p$ value } \\
\hline & $\mathbf{n}$ & $\%$ & $\mathbf{n}$ & $\%$ & \\
\hline \multicolumn{6}{|c|}{ Protozoa } \\
\hline 5 to 9 & 18 & 41.9 & 19 & 59.4 & 0.4859 \\
\hline 10 to 14 & 16 & 37.2 & 7 & 21.9 & 0.1553 \\
\hline 15 to 19 & 0 & 0.0 & 2 & 6.3 & 0.0952 \\
\hline \multicolumn{6}{|c|}{ Helminths } \\
\hline 5 to 9 & 6 & 14.0 & 12 & 37.5 & $0.0185^{*}$ \\
\hline 10 to 14 & 8 & 18.6 & 2 & 6.3 & 0.1214 \\
\hline \multicolumn{6}{|c|}{0} \\
\hline 15 to 19 & 0 & .0 & 1 & 3.1 & 0.2451 \\
\hline
\end{tabular}

* p value significant by the $\mathrm{Z}$ Test considering a $5 \%$ significance level. Source: Authors.

\section{Discussion}

The prevalence of enteroparasites in students in a Guarani indigenous village in southern Brazil was evaluated before and after mass treatment of the villagers with anthelmintic medication. There was no significant difference in the frequency of enteroparasites between the first collection of feces and the second collection, performed after treatment of the population with ABZ, except for the frequency of E. histolytica/E. dispar cysts, which was higher after treatment.

During the first examination, the most frequently observed species were the protozoa Giardia duodenalis (41.9\%), Entamoeba coli (41.9\%) and Endolimax nana (37.2\%), and the helminth Hymenolepis nana (23.3\%). These results are similar to those observed in other studies with indigenous populations from Paraná (Scolari et al, 2000; Novak et al, 2016; Moura et al, 2010) and from other locations (Anderson et al., 2014, Fontbonne et al., 2001, Oliveira et al., 2016), although the majority of them had a lower frequency of $H$. nana. Kato-Katz method was not used to assess the parasitic load of geohelminths, which would be a limiter for the assessment.

ABZ was the choice to control parasitic infections in general in the studied population. It has been used in millions of individuals in several countries for the treatment of geo-helminthiasis. It has few side effects and low toxicity, since it is poorly absorbed by the intestinal mucosa and is rapidly eliminated by the body. Its administration in a single dose offers an advantage for use in geo-helminth infection control campaigns, in addition to presenting a wide spectrum and low cost. It can also be used to treat giardiasis, however the effective dosage is $400 \mathrm{mg} /$ day, for 5 days. This medication is available free of charge by the Brazilian Unified Health System for the control of geo-helminthiasis, is presented as chewable tablets of $400 \mathrm{mg}$, administered in a single dose (Silva et al., 2016b).

It is noteworthy in this study that, after mass treatment of the indigenous population of the village, although there was no significant reduction in the number of helminth infections, infections by geo-helminths were no longer detected among the students evaluated. Considering that the establishment of control through mass administration of antiparasitic drugs is directed at these pathogens, it could be said that the measure adopted was effective (Montresor et al, 1998; Andreson et al., 2014). However, the highest prevalences of parasitic infections in the indigenous students investigated was caused by protozoa, which 
did not decrease after the drug intervention, with an increase in the number of infections by E. histolytica/dispar being observed. Other authors have also pointed out that protozoa like Entamoeba spp. and G. duodenalis were more common in indigenous children, while A. lumbricoides and hookworms were more common in adults (Anderson et al, 2014). Intestinal protozoa may be non-pathogenic, but some species such as E. histolytica, G. duodenalis and Blastocystis hominis are responsible for cases of diarrhea, malabsorption and malnutrition (Oliveira et al., 2016). These enteroparasites can be transmitted by water, food or direct contact between people, and can contribute to impaired school performance and physical development of children (Fontbonne et al, 2001). The public health problem be evident with this infotmations.

Eggs of $H$. nana remained present after treatment, increasing the frequency of this helminth from $23.3 \%$ to $43.8 \%$, although there was not a significant increase. They present little resistance in the peridomestic external environment, and the transmission of himenolepiasis usually occurs in intradomiciliary environments. The treatment indicated for this parasitosis is carried out with praziquantel (Chai, 2013) and imidazole derivatives such as ABZ may have questionable effectiveness. Cultural characteristics of indigenous peoples, such as the large number of people living in the same house, together with poor hygiene conditions, can explain the results observed (Toledo et al., 2009; Novak \& Mota, 2016, Ospina et al., 2018).

There was a high frequency of polyparasitism (48.8\%) before mass treatment, and it remained high (53.1\%) after the control action. These results corroborate other studies that also showed multiple infections by enteroparasites in most cases in indigenous populations, even after the adoption of control measures (Toledo at al, 2009; Moura et al., 2010; Andreson et al., 2013; Rajoo et al., 2017; Ospina et al., 2018).

Among the indigenous school-children in this study, the age group most affected was five to nine years, in which it was observed a significant increase $(\mathrm{p}=0.0185)$ in the frequency of helminth infection, from $14 \%$ to $37.4 \%$, after mass treatment of the population. Younger children are the most important risk group, as they are in continuous contact with contaminated soil and their hygienic habits are not yet properly developed (Silva et al., 2016a). This fact highlights the importance of adopting other control measures in addition to pharmacological measures. Although there is a recommendation that, in order to assess parasitological health indicators, the effective reduction of the parasitic burden is observed (Montresor et al., 1998), no quantitative method was applied during the coproparasitological examinations carried out, constituting a limitation of this study. This also prevented verifying the impact of the measure adopted on the intensity of geo-helminth infections.

The persistence of high rates of intestinal parasitism even after prophylactic treatment indicates the need to carry out the appropriate diagnosis and treatment, since the medication can be ineffective, as the treatment needs to be directed to the species of parasite that the individual hosts. In addition, a non-specific treatment can cause alterations in the behavior of the parasite and cause adverse symptoms (Ekpo et al., 2008).

In addition to drug treatment, the provision and use of basic hygiene materials and health education regarding the modes of transmission and prevention of these intestinal parasites, as well as improvements in basic sanitation conditions, would be control measures to be adopted simultaneously (Liao et al., 2017). Such measures could provide better conditions for the development and growth of indigenous children ( Diehl e Grassi, 2010; Brandelli et al., 2012; Andreson et al., 2014; Belizario et al., 2011).

\section{Final Considerations}

It was concluded that the frequency of enteroparasitosis in indigenous school-children belonging to the Guarani ethnic group, in a village in the State of Paraná, Southern Brazil, was high and did not decrease after the mass treatment of the population with anthelmintic medication. The mass treatment regimen with ABZ, adopted as the only control measure, was not 
effective against enteroparasites in these school-children, although geo-helminth infections were no longer detected after the adoption of the treatment strategy.

The benefits for the community in the long-term require sanitary improvements and additional educational programs in order to prevent reinfection by intestinal protozoa, which remained frequent in this study. A new observation can be carried out after the implementation of other control actions to reassess the health conditions of this population.

\section{Acknowledgments}

We gratefully acknowledge the indigenous health team and the indigenous leaders of Aldeia Tekoha Ocoy, in Santa Rosa do Ocoy, Paraná, Brazil. Acknowledgments too the Ministry of Education of the Government of Brazil through PROEXT, for the financial support.

The authors declare that theres is not conflict of interest.

\section{References}

Anderson, R., Truscott, J. \& Hollingsworth, T. D. (2014) The coverage and frequency of mass drug administration required to eliminate persistent transmission of soil-transmitted helminths. Philos Trans R Soc Lond B Biol Sci 369(1645):20130435. http://doi.org/10.1098/rstb.2013.0435

Belizario, V. Y., Totanes, F. I. G., de Leon, W. U., Lumampao, Y. F. \& Ciro R. N. T. (2011) Soil-transmitted helminth and other intestinal parasitic infections among school children in indigenous people communities in Davao del Norte, Philippines. Acta Trop, 120(1):S12-S18. http://doi.org/10.1016/j.actatropica.2011.02.010

Brandelli, C. L. C., Carli, G.A., Macedo, A. J. \& Tasca, T. (2012) Intestinal parasitis mand socio-environmental factors among Mbyá-Guarani indians, Porto Alegre, Rio Grande do Sul, Brazil. Rev Inst Med Trop Sao Paulo, 54(3):119-122. https://doi.org/10.1590/S0036-46652012000300001

Brazilian Institute of Geography and Statistics - IBGE. (2020) Avaiable in: https://indigenas.ibge.gov.br/

Chai, J. Y. (2013) Praziquantel treatment in trematode and cestode infections: an update. Infect Chemother, Mar;45(1):32-43. http://doi.org/10.3947/ic.2013.45.1.32

Coimbra, J.R. CEA, Santos RV, Escobar AL. (2005) Epidemiologia e saúde dos povos indígenas no Brasil. Rio de Janeiro: Editora FIOCRUZ.

Diehl, E.E., Grassi, F. (2010) Uso de medicamentos em uma aldeia Guarani do litoral de Santa Catarina, Brasil. Cad Saude Publica, 26(8):1549-1560. https://doi.org/10.1590/S0102-311X2010000800009

Echagüe, G., Sosa, L., Díaz, V., Ruiz, I., Rivas, L., Granado, D., Funes, P., Zenteno, J., Pistilli, N. \& Ramírez, M. (2015) Enteroparasitosis en niños bajo 5 años de edad, indígenas y no indígenas, de comunidades rurales del Paraguay. Rev Chilena Infectol, 32(6),649-657. http://doi.org/10.4067/S071610182015000700006

Ekpo, U.F., Odoemene, S.N., Mafiana, C.F. \& Sam-Wobo, S.O. (2008) Helminthiasis and Hygiene Conditions of Schools in Ikenne, Ogun State, Nigeria. PLoS Negl Trop Dis, 2(1):e146. http://doi.org/10.1371/journal.pntd.0000146

Elghareeb, A. S., Younis, M. S., El Fakahany, A. F., Nagaty, I.M. \& Nagib, M.M. (2015) Laboratory diagnosis of Blastocystis spp. In diarrheic patients. Trop Parasitol, 5(1): 36-41. http://doi.org/10.4103/2229-5070.149919

Faust, E.C., Sawitz, W. \& Tobie J. (1939) Comparative efficiency of various techniques for diagnosis of protozoa and helminthes in feces. J Parasit, Jun 25:241-62.

Faustino, R.C., Chaves, M., Toledo, M.J.O., Mota, L.T., Angelis-Neto, G. \& Nanni, M.R. (2008) Intervenções pedagógicas em educação para a saúde realizadas junto aos grupos indígenas Kaingang de Ivai e Faxinal no Paraná. Cienc Cuid Saude, 6 (Suplem. 2):433-441. http://doi.org/10.4025/cienccuidsaude.v6i0.5353

Fontbonne, A., Freese-de-Carvalho, E., Acioli, M. B., Sá, G. A. \& Cesse, E. A. P. (2001) Fatores de risco para poliparasitismo intestinal em uma comunidade indígena de Pernambuco, Brasil. Cad Saude Publica, Mar-abr;17(2):367-373. https://doi.org/10.1590/S0102-311X2001000200011

Hotez, P.J. (2009) One World Health: Negleted Tropical Diseases in a flat world. PLoS Negl Trop Dis, 3(4):e405. http://doi.org/10.1371/journal.pntd.0000405

Liao, C.W., Chiu, K.C., Chiang, I.C., Cheng, P.C., Chuang, T.W., Kuo, J.H., Tu, Y.H. \& Fan, C.K. (2017) Prevalence and Risk Factors for Intestinal Parasitic Infection in Schoolchildren in Battambang, Cambodia. Am J Trop Med Hyg, 96(3),583-588. http://doi.org/10.4269/ajtmh.16-0681

Lutz A. (1919) O Schistosomum mansoni e a schistosomose segundo observações feitas no Brasil. Mem Inst Oswaldo Cruz,11(1):121-55.

Ministério da Saúde Governo do Brasil. (2018) Practical Guide to the Control of Geo-Helminths in Brazil. Department of Surveillance of Communicable Diseases. Brasília. 
Research, Society and Development, v. 10, n. 11, e187101119524, 2021

(CC BY 4.0) | ISSN 2525-3409 | DOI: http://dx.doi.org/10.33448/rsd-v10i11.19524

Montresor, A., Crompton, D.W.T., Hall, A., Bundy, D.A.P. \& Savioli, L. (1998) Guidelines for the evaluation of soil transmitted helminthiasis and schistosomiasis at community level. World Health Organization. Geneva:WHO/CTC/ SIP/98.

Moura, F. T., Falavigna, D.L.M., Mota, L.T. \& Toledo, M.J.O. (2010) Enteroparasite contamination in peridomiciliar soils of two indigenous territories, State of Paraná, southern Brazil. Rev Panam Salud Publica, 27(6):414-22. http://doi.org/10.1590/S1020-49892010000600002

Nishi, L., Bergamasco, R., Toledo, M.J.O., Falavigna, D.L.M., Gomes, M.L., Mota, L.T. \& Falavigna-Guilherme, A.L. (2009) Giardia spp. and Cryptosporidium spp. in the Ivai indigenous land, Brazil. Vector Borne Zoonotic Dis, Oct;9:543-547. https://doi.org/10.1590/S0102-311X2006000500015

Novak, E.S. \& Mota, L.T. (2016) A Política Indigenista e os Territórios Indígenas no Paraná. Fronteiras: Revista de História, Jul/Dez;18(32):76-97.

Oliveira, R.A., Gurgel-Goncalves, R. \& Machado, E. R. (2016) Intestinal parasites in two indigenous ethnic groups in northwestern Amazonia. Acta Amaz, 4(3): 241-246. https://doi.org/10.1590/1809-4392201505883

Ospina Lozano, E.J. (2018) Epidemiología sociocultural de los padecimientos gastrointestinales en niños y niñas del pueblo Nasa, Colombia. Rev Univ Ind Santandr Salud, 50(4):328-340. http://dx.doi.org/10.18273/revsal.v50n4-2018006

Pereira, A. S., Shitsuka, D. M., Parreira, F.J. \& Shitsuka, R. (2018) Metodologia da pesquisa cientifica. [free e-book]. Santa Maria: UAB/NTE/UFSM. https://repositorio.ufsm.br/bitstream/handle/1/15824/Lic_Computacao_Metodologia-Pesquisa-Cientifica.pdf

Rajoo, Y., Ambu, S., Lim, Y.A.L., Rajoo, K., Tey, S.C., Lu. C.W. \& Ngui, R. (2017) Negleted Intestinal Parasites, malnutrition and associated key factors: a Population Based Cross-Sectional study among Indigenous Comunities in Sarawak, Malaysia. PLoS One, 12(1)e0170174. https://doi.org/10.1371/journal.pone.0170174

Scolari, C., Torti, C., Beltrame, A., Matteelli, A., Castelli, F., Gulletta, M., Ribas, M., Morana, S. \& Urbani, C. (2000) Prevalence and distribuition of soil transmitted helminth (STH) infections in urban and indigenous school children in Ortigueira, State of Parana, Brazil: implications for control. Trop Med Int Health, 5(4);302-307. http://doi.org/10.1046/j.1365-3156.2000.00549.x

Silva, J. B., Bossolani, G. D. P., Piva, C., Dias, G. B. M., Ferreira, J. G., Rossoni, D.F., Mota, L.T. \& Toledo, M.J.O. (2016) Spatial distribution of intestinal parasitic infections in a Kaingáng indigenous village from Southern Brazil. Intern Journal of Environ Health Research, 26:5-6,578-588, http://doi.org/10.1080/09603123.2016.1217312

Silva, J. B., Piva, C., Falavigna-Guilherme, A. L., Rossoni, D. F. \& Toledo, M.J.O. (2016) Spatial distribution and enteroparasite contamination in peridomiciliar soil and water in the Apucaraninha Indigenous Land, Southern Brazil. Environ Monit Assess, Apr;188(4):217.http://doi.org/10.1007/s1066101652164

Toledo, M. J. O., Paludetto, A. W., Moura, F. T., Nascimento, E. S., Chaves, M., Araújo, S. M. \& Mota, L. (2009) Evaluation of enteroparasite control activities in a Kaingang community of Southern Brazil. Rev Saude Publica, 43(6):981-90. https://doi.org/10.1590/S0034-89102009005000083 